\title{
The effect of depth and sediment type on the spatial distribution of shallow soft-bottom amphipods along the southern Portuguese coast
}

\author{
Susana Carvalho $\cdot$ Marina R. Cunha $\cdot$ Fábio Pereira $\cdot$ \\ P. Pousão-Ferreira $\cdot$ M. N. Santos $\cdot$ M. B. Gaspar
}

Received: 1 February 2011 / Revised: 20 November 2011 / Accepted: 24 November 2011 / Published online: 10 December 2011

(C) Springer-Verlag and AWI 2011

\begin{abstract}
The present study provides updated information on amphipod assemblages of the southern Portuguese coast, the most south-western part of continental Europe. The influence of depth and sediment type on the spatial distribution of shallow soft-bottom amphipods was tested by means of univariate and multivariate methods. Samples were collected down to $40 \mathrm{~m}$ depth within areas ranging from very fine sand to gravel. The ratio between density and diversity was found to increase with depth and from coarser to finer sediments. Both physical variables tested were found to play a major role in structuring amphipod assemblages. However, some dominance of depth was evident as samples were mainly separated according to this variable. Moreover, while only 15 taxa were common to all depth levels, 35 were collected from all sediment types. Both depth and sediment type may override the potential effects of geographical location, as samples from different areas along the southern Portuguese coast were biologically related. A peculiar habitat was sampled in this study: a maerl bed, which was confirmed to be a hotspot of density. Nevertheless, this habitat did not harbor a distinct amphipod assemblage but some taxa such as Caprella spp., Lembos websteri, lysianassids and Gammarella fucicola were preferentially collected there. The biogeographical analysis
\end{abstract}

Communicated by Heinz-Dieter Franke.

S. Carvalho $(\bowtie) \cdot$ F. Pereira $\cdot$ P. Pousão-Ferreira $\cdot$ M. N. Santos M. B. Gaspar

Instituto Nacional de Recursos Biológicos (INRB, I.P.)/IPIMAR, Av. 5 de Outubro s/n, 8700-305 Olhão, Portugal

e-mail: scarvalho@ipimar.pt

M. R. Cunha

Departamento de Biologia \& CESAM, Universidade de Aveiro, Campus de Santiago, 3810-193 Aveiro, Portugal pointed out the occurrence of $8 \%$ of Mediterranean endemic species, confirming the influence of the Mediterranean Sea beyond the Strait of Gibraltar, and the AtlanticMediterranean feature of the amphipod fauna of this geographically relevant area. The present results support the need to interpret the spatial distribution patterns of marine species in relation to the combined effect of depth and sediment characteristics.

Keywords Benthos - Amphipoda - Soft bottom · Spatial distribution · Depth - Sediment - Biogeography · Southern Portuguese coast

\section{Introduction}

Marine soft-bottom communities support a high diversity of species with different ecological characteristics. Depth and sediment type have been pointed out as important factors affecting the distribution of marine macrobenthic communities (Cunha et al. 1997; Hoey et al. 2004; Mackie et al. 1997; Martínez and Adarraga 2001; Snelgrove 1998). Along a depth gradient, species are distributed according to their ability to cope with both physical (e.g., sediment composition, hydrodynamics) and biological factors (e.g., food, competition, predation).

Among the macrobenthic fauna, Amphipoda (Crustacea: Peracarida) represent a major taxonomic component, both in terms of density and diversity, inhabiting marine softbottom habitats from polar to tropic areas and from the tidal to the abyssal zone (Marques and Bellan-Santini 1990a). Moreover, amphipods are useful bioindicators of seawater and sediment quality (Conradi et al. 1997; Guerra-García and García-Gómez 2002), reflecting changes in environmental conditions that result from natural or anthropogenic 
disturbances. Therefore, the knowledge of the structure and composition of amphipod assemblages may be of major importance to assess changes in the marine environment as well as for management purposes (e.g., conservation areas).

The continental shelf off the Portuguese south coast is of particular interest due to the combined influence of Atlantic and Mediterranean currents. Nevertheless, few studies have addressed the benthic communities of this area (Monteiro Marques 1979; Sousa Reis et al. 1982). Most studies have focused on the Ria Formosa and Alvor lagoons (e.g., Carvalho et al. 2006b; Carvalho et al. in press; Gamito 1989; Lock and Mees 1999; Marques and Bellan-Santini 1990b; Rodrigues and Dauvin 1987; Sprung 1994). Concerning amphipods, only one major work was undertaken along the southern Portuguese coast (both offshore and inshore) in the 1980s, as part of a general study on amphipods of Portuguese coastal waters (Marques and Bellan-Santini 1985, 1986, 1987, 1990a, b, 1991, 1993). Therefore, there is a lack of updated knowledge concerning this relevant faunal group.

The present work provides updated information on the distribution and ecology of benthic amphipods of shallow coastal areas, increasing our knowledge on the biodiversity of the most south-western part of continental Europe. A biogeographic analysis of the amphipod species was undertaken. Data were also analyzed on the basis of species composition, density and habitat features, namely depth and sediment type. The depth gradient considered comprises both exposed and sheltered zones. The influence of two major physical variables (depth and sediment type) on the spatial distribution of shallow water amphipod assemblages was tested.

\section{Materials and methods}

Study area

The study area covers most of the southern Portuguese coast (Fig. 1). Samples were collected in different subtidal zones from 1 to $37 \mathrm{~m}$ depth. For the purpose of the present study, samples were allocated to one of the following three depth levels: $<10 \mathrm{~m}, 10-25 \mathrm{~m}$ and $>25 \mathrm{~m}$ deep, based on Dolbeth et al. (2007).

\section{Data source}

The biological material was gathered within the framework of several monitoring projects carried out between 2000 and 2006 along the southern Portuguese coast. Therefore, samples are not evenly distributed along the coast; deeper stations are scarce in the eastern part of the study area (Fig. 1). This is a common handicap already indicated in similar studies (Hoey et al. 2004; Zenetos et al. 2000). Most samples were collected during spring-summer seasons (Table 1). Generally, subtidal samples were collected using a Van Veen grab $\left(0.05 \mathrm{~m}^{2}\right)$ (Table 1$)$. However, some samples from shallow waters (down to $6 \mathrm{~m}$ depth) were collected by scuba divers using hand-cores (three core samples as one replicate; combined area of $0.018 \mathrm{~m}^{2}$ ) (Table 1$)$. Therefore, in order to compare different samples, abundance values were standardized to $1 \mathrm{~m}^{2}$ (Zenetos et al. 2000). Regardless of the sampling method, at least three replicates were taken per site in a total of 211 samples. In the laboratory, amphipods were sorted and specimens were identified to the lowest possible taxonomic level and counted under a binocular stereomicroscope. Species' names are in accordance with the World Register of Marine Species-WoRMS (http://www. marinespecies.org/aphia.php? $\mathrm{p}=$ search).

\section{Sediment samples}

The information on sediment classification was gathered from different project reports. Within the study area, sediments ranged from very fine sand to gravel. Fine, medium, and coarse sand were also well represented (Table 1). Sediments were grouped into three types: very fine to fine sands (VF-F), medium sands (M), and coarse sand to gravel (C-G).

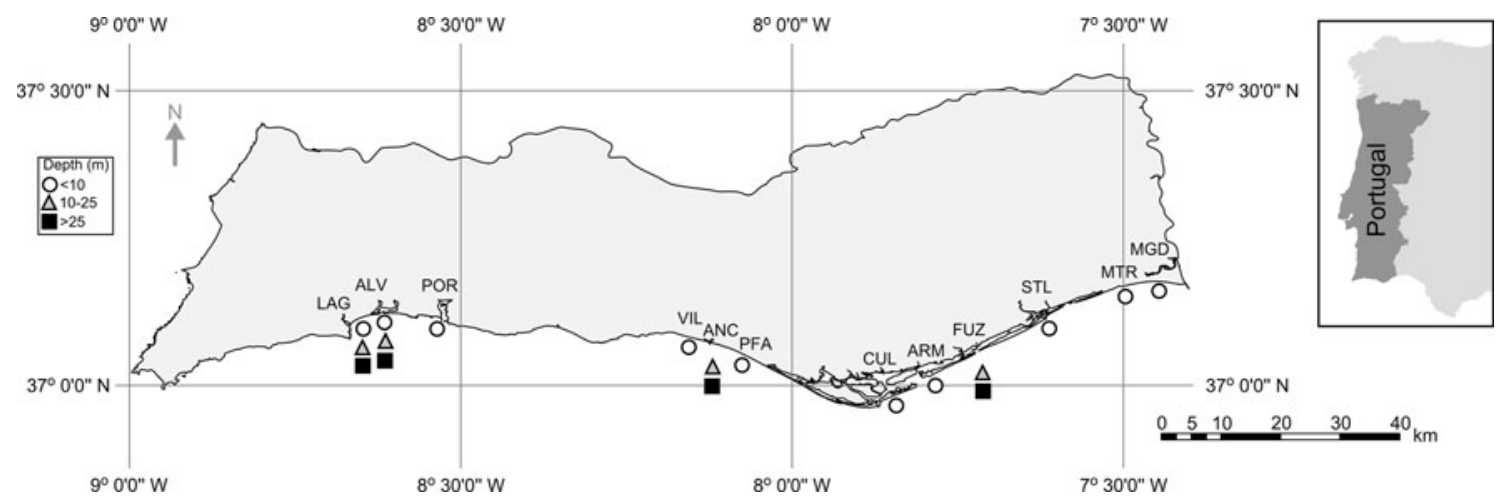

Fig. 1 Southern Portuguese coast; location of sampling stations 
Table 1 Information on depth, sediment type, sampling method and date for all sites analyzed in the present study

\begin{tabular}{|c|c|c|c|c|}
\hline Site & Depth & Sediment type & $\begin{array}{l}\text { Sampling } \\
\text { method }\end{array}$ & $\begin{array}{l}\text { Sampling } \\
\text { date }\end{array}$ \\
\hline LAG4 & 15 & Very coarse sand & Van Veen grab & Spring 2006 \\
\hline LAG5 & 25 & Fine sand & Van Veen grab & Spring 2006 \\
\hline LAG6 & 30 & Fine sand & Van Veen grab & Spring 2006 \\
\hline LAG8 & 5 & Mean sand & Van Veen grab & Spring 2006 \\
\hline LAG12 & 8 & Mean sand & Van Veen grab & Spring 2006 \\
\hline ALV2 & 24 & Very fine sand & Van Veen grab & Spring 2000 \\
\hline ALV3 & 24 & Very fine sand & Van Veen grab & Spring 2000 \\
\hline ALV4 & 26 & Coarse sand & Van Veen grab & Spring 2000 \\
\hline ALV5 & 12 & Mean sand & Van Veen grab & Spring 2000 \\
\hline ALV6 & 13 & Mean sand & Van Veen grab & Spring 2000 \\
\hline ALV7 & 8 & Mean sand & Van Veen grab & Spring 2000 \\
\hline ALV8 & 4 & Coarse sand & Van Veen grab & Spring 2000 \\
\hline ALV9 & 13 & Fine sand & Van Veen grab & Spring 2000 \\
\hline POR1 & 6 & Mean sand & Corer & Spring 2004 \\
\hline POR2 & 6 & Mean sand & Corer & Spring 2004 \\
\hline POR3 & 6 & Mean sand & Corer & Spring 2004 \\
\hline VIL1 & 6 & Coarse sand & Corer & Spring 2004 \\
\hline VIL2 & 6 & Coarse sand & Corer & Spring 2004 \\
\hline VIL3 & 6 & Coarse sand & Corer & Spring 2004 \\
\hline ANC2 & 13 & Fine sand & Van Veen grab & Winter 2001 \\
\hline ANC3 & 31 & Very fine sand & Van Veen grab & Winter 2001 \\
\hline ANC4 & 32 & Very fine sand & Van Veen grab & Winter 2001 \\
\hline ANC5 & 20 & Coarse sand & Van Veen grab & Winter 2001 \\
\hline ANC6 & 37 & Very fine sand & Van Veen grab & Winter 2001 \\
\hline ANC7 & 21 & Coarse sand & Van Veen grab & Winter 2001 \\
\hline ANC8 & 31 & Very fine sand & Van Veen grab & Winter 2001 \\
\hline ANC9 & 29 & Coarse sand & Van Veen grab & Winter 2001 \\
\hline ANC10 & 34 & Mean sand & Van Veen grab & Winter 2001 \\
\hline ANC11 & 12 & Coarse sand & Van Veen grab & Winter 2001 \\
\hline ANC12 & 15 & Coarse sand & Van Veen grab & Winter 2001 \\
\hline ANC13 & 25 & Fine sand & Van Veen grab & Winter 2001 \\
\hline PFA1 & 6 & Fine sand & Corer & Spring 2004 \\
\hline PFA2 & 6 & Fine sand & Corer & Spring 2004 \\
\hline PFA3 & 6 & Fine sand & Corer & Spring 2004 \\
\hline PFA4 & 1 & Fine sand & Van Veen grab & Spring 2004 \\
\hline PFA5 & 1 & Fine sand & Van Veen grab & Spring 2004 \\
\hline PFA6 & 1 & Fine sand & Van Veen grab & Spring 2004 \\
\hline PFA7 & 1 & Mean sand & Van Veen grab & Spring 2004 \\
\hline PFA8 & 1 & Mean sand & Van Veen grab & Spring 2004 \\
\hline PFA9 & 1 & Mean sand & Van Veen grab & Spring 2004 \\
\hline CUL1 & 6 & Mean sand & Corer & Spring 2004 \\
\hline CUL2 & 6 & Mean sand & Corer & Spring 2004 \\
\hline CUL3 & 6 & Mean sand & Corer & Spring 2004 \\
\hline ARM1 & 6 & Fine sand & Corer & Spring 2004 \\
\hline ARM2 & 6 & Fine sand & Corer & Spring 2004 \\
\hline FUZ2 & 27 & Fine sand & Van Veen grab & Summer 2001 \\
\hline
\end{tabular}

Table 1 continued

\begin{tabular}{|c|c|c|c|c|}
\hline Site & Depth & Sediment type & $\begin{array}{l}\text { Sampling } \\
\text { method }\end{array}$ & $\begin{array}{l}\text { Sampling } \\
\text { date }\end{array}$ \\
\hline FUZ3 & 23 & Fine sand & Van Veen grab & Summer 2001 \\
\hline FUZ4 & 30 & Very fine sand & Van Veen grab & Summer 2001 \\
\hline FUZ5 & 26 & Fine sand & Van Veen grab & Summer 2001 \\
\hline FUZ6 & 13 & Very fine sand & Van Veen grab & Summer 2001 \\
\hline FUZ7 & 28 & Very fine sand & Van Veen grab & Summer 2001 \\
\hline STL1 & 6 & Coarse sand & Corer & Spring 2004 \\
\hline STL2 & 6 & Coarse sand & Corer & Spring 2004 \\
\hline STL3 & 6 & Coarse sand & Corer & Spring 2004 \\
\hline MRT1 & 6 & Coarse sand & Corer & Spring 2004 \\
\hline MRT2 & 6 & Coarse sand & Corer & Spring 2004 \\
\hline MRT3 & 6 & Coarse sand & Corer & Spring 2004 \\
\hline MGD1 & 6 & Coarse sand & Corer & Spring 2004 \\
\hline MGD2 & 6 & Coarse sand & Corer & Spring 2004 \\
\hline
\end{tabular}

Data analysis

Varying sample sizes do not allow for reliable comparisons of species richness across the study area, as this variable will increase with sample size (Magurran 1988). Therefore, rarefaction curves developed by Sanders (1968) and modified by Hurlbert (1971) were used to provide an unbiased estimate of species richness, as the estimated number of species in a subsample of 50 individuals $\left[\mathrm{ES}_{(50)}\right]$. Density (ind. $\mathrm{m}^{-2}$ ) was calculated and analyzed together with $\mathrm{ES}_{(50)}$ in relation to depth and sediment type. Relationships between $\mathrm{ES}_{(50)}$ and density as a function of depth and sediment type were established through regression analyses, by fitting a linear function to raw data $(Y=b X$, no intercept in the model, as null number of species implies null density). The degree of association between variables was assessed by the correlation coefficient $(r)$, and the slopes of the linear regressions were compared using a $t$-test $\left(H_{0}: \beta_{\mathrm{A}}=\beta_{\mathrm{B}} ; H_{\mathrm{A}}: \beta_{\mathrm{A}} \neq \beta_{\mathrm{B}}\right)(\operatorname{Zar} 1996)$.

The amphipod community structure was analyzed by a combination of uni- and multivariate techniques included in the PRIMER v5 software (Clarke and Gorley 2001). Faunal relationships were assessed by a hierarchical cluster analysis (CLUSTER) using the Bray-Curtis coefficient and the unweighted pair-group average algorithm. As data were not homogeneously sampled, a presence/absence transformation was chosen in order to remove the effect of varying sample sizes and seasonality (Ysebaert et al. 2002). Correlations between density of the most abundant amphipods with depth and sediment type were performed using the STATISTICA software. Species showing significant correlations were selected, and subsequently, a one-way ANOVA was performed for factors 'depth' (orthogonal, 3 levels: $<10 \mathrm{~m} ; 10-25 \mathrm{~m}$; $>25 \mathrm{~m}$ ) and 'sediment' (orthogonal, 3 levels: VF-F; M; C-G). 
Species were also assigned to different biogeographic regions adopted from Conradi and López-González (1999). The groups established were the following:

I. Mediterranean endemic

II. Atlantic, present in the Mediterranean

III. Atlantic, absent from the Mediterranean

IV. Atlantic, present in the Mediterranean and Indo-Pacific Ocean

V. Atlantic, present in the Indo-Pacific Ocean

VI. Cosmopolitan

\section{Results}

The present data set allowed the identification of 93 taxa belonging to 24 families. The most abundant families were Ampeliscidae (21.9\%), Corophiidae (19.8\%), Caprellidae (11.6\%), Urothoidae (10.6\%), and Aoridae (7.5\%).

$\mathrm{ES}_{(50)}$ and density as a function of depth and sediment type are shown in Fig. 2. Significant relationships were observed for all depth levels. The ratio density/species richness increased with depth (Fig. 2a). The comparison of slopes of the linear regressions showed that significant differences were observed between depth levels (except between all data and the 10-25 m depth level) (Fig. 2a).
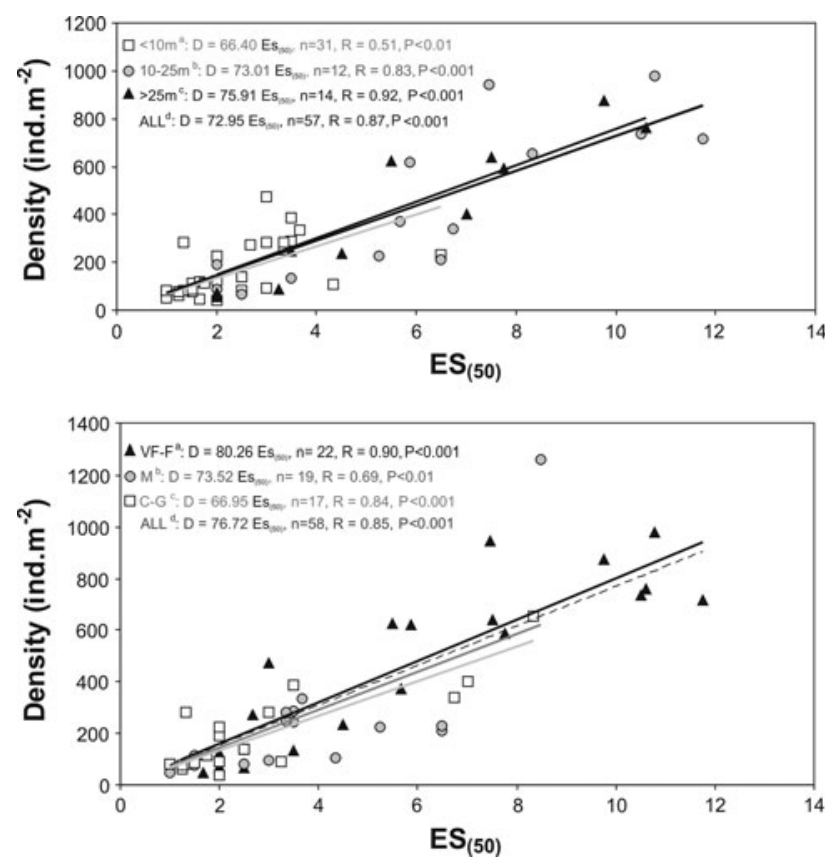

Fig. 2 Relationships between density $\left(D\right.$, ind. $\left.\mathrm{m}^{-2}\right)$ and diversity $\left(\mathrm{ES}_{(50)}=\right.$ estimated number of amphipod taxa in a subsample of 50 individuals) for different depth levels (above) and sediment types (below). Different superscript letters denote statistically significant differences between slopes of regression lines. ALL $=$ entire depth gradient and all sediment types, respectively; $V F-F$ very fine to fine sand, $M$ medium sand, $C-G$ coarse sand to gavel. For clarity, only average values per station have been plotted
Significant differences were also detected for all sediments considered (Fig. 2b). The ratio density/species richness significantly increased from coarser to finer sediments (Fig. 2b). It is worth noting that some outliers were removed from this analysis, namely samples from a maerl bottom, which turned out to be a hotspot of density. Therefore, benthic assemblages associated with maerl beds were analyzed separately with respect to faunal differences related to sediment type.

Amphipod assemblages

Multivariate analysis performed in order to assess for spatial patterns along the southern Portuguese coast is presented in Fig. 3. Density, estimated number of species, depth, and sediment classification for each site are also presented. Three main clusters were observed (I, II, III). Clusters I and II mainly comprised shallower stations with medium sand to gravel (Fig. 3). Samples of both clusters were characterized by low density and low estimated number of species. Nevertheless, while samples from cluster I presented a slightly higher mean density (cluster I: $162 \pm 119$ ind. $\mathrm{m}^{-2}$; cluster II: $152 \pm 108$ ind. $\mathrm{m}^{-2}$ ), samples from cluster II showed higher mean species richness (cluster I: $2.0 \pm 0.9$; cluster II: $2.7 \pm 0.9$ ) (Fig. 3). In contrast, cluster III (sub-clusters a and b) mainly comprised samples located at depths higher than the 10-m depth contour (Fig. 3). Both clusters, IIIa and IIIb, showed high density and number of species. Cluster IIIa mainly comprised samples located at greater depth (mean depth $25 \pm 5 \mathrm{~m}$ ) and of finer sediments than cluster IIIb (mean depth $12 \pm 6 \mathrm{~m})$. Higher species richness was associated with cluster IIIa (cluster IIIa: $8.1 \pm 2.1$; cluster IIIb: $6.2 \pm 1.6$ ), while cluster IIIb presented higher density (cluster IIIa: $683 \pm 161$ ind. $\mathrm{m}^{-2}$; cluster IIIb: $780 \pm 1111$ ind. $\mathrm{m}^{-2}$ ).

Species affinities

Some amphipod taxa showed a preferential distribution to specific depth levels. Fifteen taxa, however, were common to all depth levels: Atylus vedlomensis (Bate \& Westwood, 1862), Cheirocratus sundevalli (Rathke, 1843), Medicorophium annulatum (Chevreux, 1908), Lembos websteri Bate, 1857, Leptocheirus pectinatus (Norman, 1869), Leucothoe oboa Karaman, 1971, Orchomenella nana (Kroyer, 1846), Perioculodes longimanus (Bate \& Westwood, 1868), Phtisica marina Slabber, 1769, Siphonoecetes (Centraloecetes) dellavallei Stebbing, 1899 and Urothoe elegans (Bate, 1857). Ampelisca spp., Caprella spp., members of the family Melitidae and Photis spp., were also common to all depth levels; these taxa, however, were not identified to species level, and the relationship between their density and depth has thus to be interpreted with caution. The most 


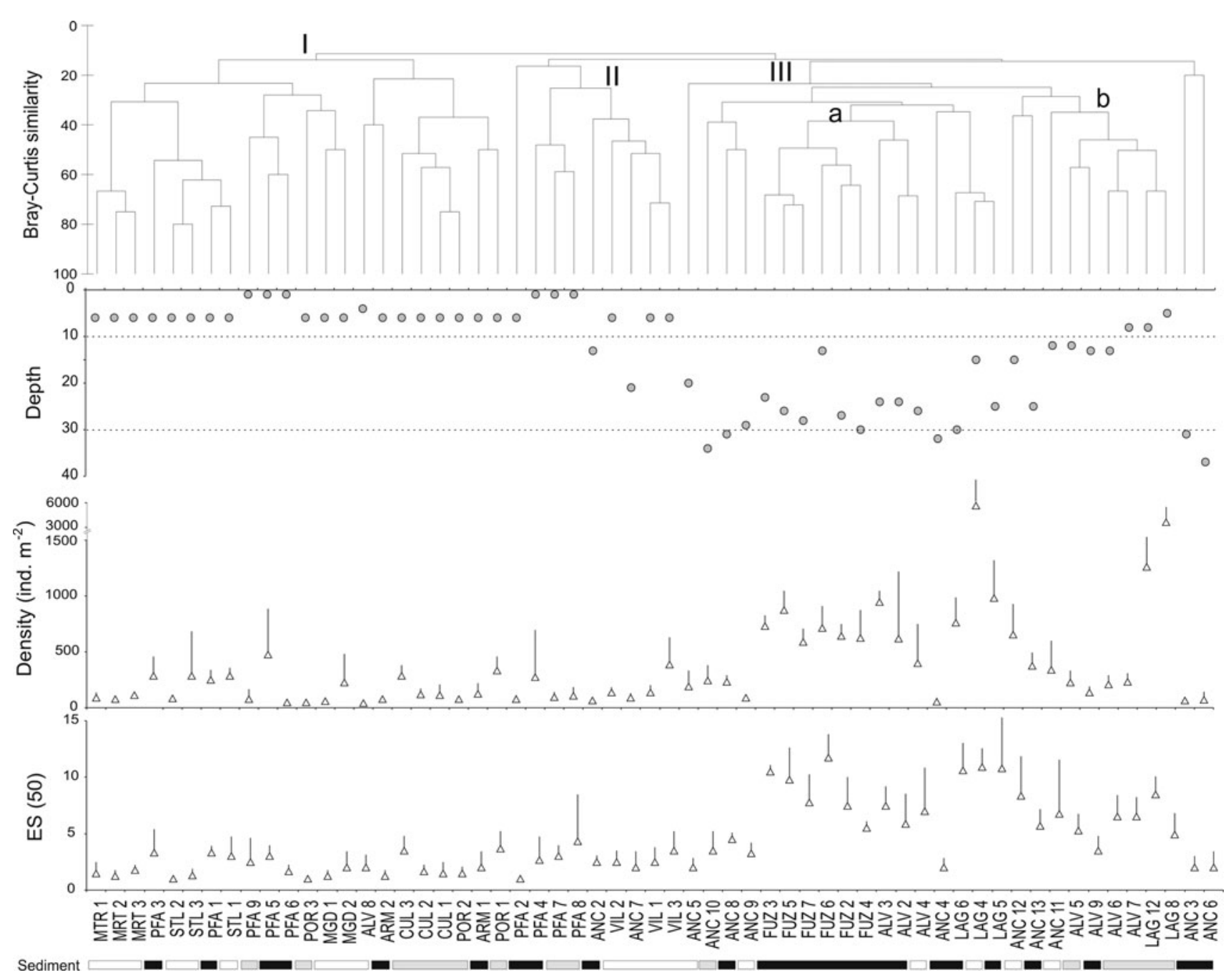

Fig. 3 Cluster diagram of sampling stations with the respective depth, sediment classification, density (+SD) and estimated number of species $\left(\mathrm{ES}_{(50)}+\mathrm{SD}\right)$. Sediment: black rectangles $=$ very fine to fine sands; gray rectangles $=$ medium sand; white rectangles $=$ coarse sand to gravel

abundant taxa as well as taxa which were exclusive to a particular depth level are listed in Table 2. Within the most abundant taxa, the intermediate and the deepest depth level shared the highest number of taxa. Nevertheless, the highest number of exclusive taxa was observed for the two upper depth levels ( $<10$ and 10-25 m). The species of the genus Siphonoecetes (Centraloecetes) and Bathyporeia were particularly abundant above $10 \mathrm{~m}$ depth, together with Urothoe grimaldii Chevreux, 1895, Urothoe poseidonis Reibish, 1905, and Perioculodes longimanus. Urothoe poseidonis and Siphonoecetes (Centraloecetes) kroyeranus Bate, 1856, were not only abundant but also exclusive of this depth level, together with other species with less expression (Table 2). Although not exclusive, the genera Ampelisca, Caprella, and Photis were well represented between the 10 and $25 \mathrm{~m}$ isobaths, as well as Harpinia antennaria Meinert, 1890, Microdeutopus armatus Chevreux, 1886, Urothoe elegans, Leptocheirus pectinatus, Leptocheirus hirsutimanus (Bate, 1862), Lembos websteri,
Leucothoe oboa, Pariambus typicus (Krøyer, 1884), and Megamphopus cornutus Norman, 1869. At depths greater than $25 \mathrm{~m}$, Maera grossimana (Montagu, 1808), Argissa hamatipes (Norman, 1869), and members of the Isaeidae were the most characteristic taxa, but only the latter two were exclusively sampled at this depth level.

The most abundant taxa per sediment type and the taxa which were exclusive to a specific sediment type are represented in Table 3. The highest number of exclusive taxa was observed in VF-F sands, while 35 taxa (37\%) were common to all sediment types. This latter group comprises taxa common to all depth levels (except Melitidae): Bathyporeia spp., Gammaropsis maculata (Johnston, 1828), Gammaropsis sp., Harpinia antennaria, Lembos sp.A, Leptocheirus hirsutimanus, Leucothoe incisa (Robertson, 1892), Lysianassidae, Maera grossimana, Megaluropus agilis Hoeck, 1889, Megamphopus cornutus, Microdeutopus armatus, Microdeutopus gryllotalpa Costa, 1853, Microprotopus maculatus Norman, 1867, Monoculodes 
Table 2 Density ( $D$-no. ind. $\mathrm{m}^{-2}$ ) of the most abundant taxa in the considered depth levels

\begin{tabular}{|c|c|c|c|c|c|}
\hline \multicolumn{2}{|l|}{$<10 \mathrm{~m}$} & \multicolumn{2}{|l|}{$10-25 \mathrm{~m}$} & \multicolumn{2}{|l|}{$>25 \mathrm{~m}$} \\
\hline Taxa & $D$ & Taxa & $D$ & Taxa & $D$ \\
\hline \multicolumn{6}{|l|}{ Most abundant taxa } \\
\hline Siphonoecetes (Centraloecetes) dellavallei & 11,140 & Ampelisca spp. & 13,840 & Ampelisca spp. & 3,980 \\
\hline Urothoe grimaldii & 2,590 & Caprella spp. & 10,040 & Harpinia antennaria & 920 \\
\hline Bathyporeia spp. & 2,540 & Harpinia antennaria & 2,620 & Microdeutopus armatus & 500 \\
\hline Siphonoecetes (Centraloecetes) kroyeranus & 1,960 & Microdeutopus armatus & 1,800 & Atylus vedlomensis & 160 \\
\hline Urothoe poseidonis & 1,500 & Photis spp. & 1,620 & Maera grossimana & 160 \\
\hline Ampelisca spp. & 1,460 & Urothoe elegans & 1,420 & Medicorophium annulatum & 140 \\
\hline Medicorophium annulatum & 1,300 & Leptocheirus pectinatus & 1,260 & Leucothoe oboa & 140 \\
\hline Urothoe cf. hesperiae & 1,110 & Urothoe cf. hesperiae & 1,240 & & \\
\hline Atylus vedlomensis & 990 & Leptocheirus hirsutimanus & 980 & & \\
\hline \multirow[t]{7}{*}{ Perioculodes longimanus } & 960 & Medicorophium annulatum & 900 & & \\
\hline & & Lembos websteri & 720 & & \\
\hline & & Leucothoe oboa & 660 & & \\
\hline & & Urothoe grimaldii & 620 & & \\
\hline & & Pariambus typicus & 600 & & \\
\hline & & Megamphopus cornutus & 600 & & \\
\hline & & Atylus vedlomensis & 560 & & \\
\hline \multicolumn{6}{|l|}{ Exclusive taxa } \\
\hline Amphilochus tenuimanus & & Caprella rapax & & Argissa hamatipes & \\
\hline Monocorophium ascherusicum & & Animoceradocus semiserratus & & Isaeidae & \\
\hline Dexamine spinosa & & Lepidepecreum longicornis & & & \\
\hline Monoculodes subnudus & & Metaphoxus pectinatus & & & \\
\hline Siphonoecetes (Centraloecetes) kroyeranus & & Urothoe pulchella & & & \\
\hline Urothoe poseidonis & & Westwoodilla $\mathrm{sp}$. & & & \\
\hline
\end{tabular}

Only taxa accounting for $80 \%$ of total density per depth level are shown. Only taxa which occurred in at least two samples from a certain depth level were considered exclusive

carinatus (Bate, 1857), Pontocrates altamarinus (Bate \& Westwood, 1862), Siphonoecetes (Centraloecetes) neapolitanus Schiecke, 1979, Urothoe grimaldii, Urothoe cf. hesperiae Conradi, Lopez-Gonzalez \& Bellan-Santini 1995, Urothoe intermedia Bellan-Santini \& Ruffo, 1986 and Urothoe pulchella (Costa, 1853). The taxa Medicorophium annulatum and Bathyporeia spp. were well represented both in fine and medium sands, while Photis spp. presented high densities in both VF-F sand and $\mathrm{C}-\mathrm{G}$ bottoms. On the other hand, Urothoe grimaldii and Urothoe cf. hesperiae were common to $\mathrm{M}$ and $\mathrm{C}-\mathrm{G}$ sediments.

A one-way ANOVA was performed for factors 'depth' and 'sediment' separately for the most abundant taxa (i.e., taxa accounting for more than $80 \%$ of abundance per depth level and sediment type). Species showing significant correlations with at least one factor are presented in Figs. 4 and 5. This analysis showed that seven taxa presented significant differences for the factor 'depth' and eight for the factor 'sediment' (Figs. 4, 5). Bathyporeia spp. and Urothoe grimaldii were more abundant at the lowest depth level
(Fig. 4). For the former taxa, significant differences were observed between stations located at this depth level and the remaining stations, while for the urothoiid, significant differences were only detected for the deepest level. Densities of Leucothoe oboa, Microdeutopus armatus, and Urothoe elegans peaked at the intermediate depth level (10-25 m) but significant differences were only detected between stations located at this level and the shallower stations $(<10 \mathrm{~m})$. On the other hand, density of Ampelisca spp. and Harpinia antennaria was significantly lower at the shallower stations when compared with the remaining stations. As to the factor 'sediment', Ampelisca spp., Harpinia antennaria, and Microdeutopus armatus were significantly more abundant in finer sediments than in the remaining sediment types (Fig. 5). On the other hand, Urothoe cf. hesperiae and Urothoe grimaldii presented significantly higher densities in medium sands than in finer sediments. In contrast to these two species, the congeneric Urothoe elegans showed significantly higher densities in very fine to fine sands than in coarse sand to gravel. Atylus vedlomensis was significantly 
Table 3 Density $\left(D-n o\right.$. ind. $\mathrm{m}^{-2}$ ) of the most abundant taxa for the different sediment types

\begin{tabular}{|c|c|c|c|c|c|c|c|}
\hline \multicolumn{2}{|l|}{$\mathrm{VF}-\mathrm{F}$} & \multicolumn{2}{|l|}{ M } & \multicolumn{2}{|l|}{$\mathrm{C}-\mathrm{G}$} & \multicolumn{2}{|l|}{ Maerl } \\
\hline Taxa & $D$ & Taxa & $D$ & & $D$ & Taxa & $D$ \\
\hline \multicolumn{8}{|l|}{ Most abundant taxa } \\
\hline Ampelisca spp. & 15,740 & $\begin{array}{l}\text { Siphonoecetes } \\
\quad \text { (Centraloecetes) } \\
\text { dellavallei }\end{array}$ & 11,160 & Ampelisca spp. & 1,830 & Caprella spp. & 9,780 \\
\hline Harpinia antennaria & 3,460 & Bathyporeia spp. & 2,010 & Urothoe grimaldii & 1,340 & Lembos websteri & 640 \\
\hline $\begin{array}{l}\text { Siphonoecetes (Centraloecetes) } \\
\text { kroyeranus }\end{array}$ & 1,940 & Ampelisca spp. & 1,670 & Atylus vedlomensis & 1,230 & $\begin{array}{c}\text { Leptocheirus } \\
\text { pectinatus }\end{array}$ & 620 \\
\hline Microdeutopus armatus & 1,900 & Urothoe grimaldii & 1,570 & Urothoe poseidonis & 1,050 & Photis spp. & 560 \\
\hline Urothoe elegans & 1,340 & Urothoe cf. hesperiae & 1,380 & Urothoe cf. hesperiae & 910 & Lysianassidae & 480 \\
\hline Medicorophium annulatum & 900 & Mediorophium annulatum & 1,200 & Perioculodes longimanus & 780 & $\begin{array}{l}\text { Cheirocratus } \\
\text { sundevalli }\end{array}$ & 360 \\
\hline Photis spp. & 750 & Pontocrates arenarius & 810 & Leptocheirus hirsutimanus & 540 & & \\
\hline Pariambus typicus & 620 & & & Leptocheirus pectinatus & 450 & & \\
\hline Leucothoe oboa & 580 & & & Autonoe denticarpus & 440 & & \\
\hline Bathyporeia spp. & 550 & & & Megaluropus agilis & 420 & & \\
\hline \multirow[t]{8}{*}{ Perioculodes longimanus } & 500 & & & Leucothoe incisa & 350 & & \\
\hline & & & & Photis spp. & 340 & & \\
\hline & & & & Abludomelita obtusata & 340 & & \\
\hline & & & & Phtisica marina & 300 & & \\
\hline & & & & Melitidae & 250 & & \\
\hline & & & & Medicorophium annulatum & 240 & & \\
\hline & & & & Megamphopus cornutus & 220 & & \\
\hline & & & & Pontocrates altamarinus & 200 & & \\
\hline \multicolumn{8}{|l|}{ Exclusive taxa } \\
\hline Apherusa bispinosa & & Dexamine spinosa & & Abludomelita obtusata & & Gammarella fucic & ola \\
\hline \multicolumn{8}{|l|}{ Apherusa ovalipes } \\
\hline \multicolumn{8}{|l|}{ Argissa hamatipes } \\
\hline \multicolumn{8}{|l|}{ Atylus guttatus } \\
\hline \multicolumn{8}{|l|}{ Caprella rapax } \\
\hline \multicolumn{8}{|l|}{ Medicorophium runcicorne } \\
\hline \multicolumn{8}{|l|}{ Harpinia crenulata } \\
\hline \multicolumn{8}{|l|}{ Isaeidae } \\
\hline \multicolumn{8}{|l|}{ Leucothoe spinicarpa } \\
\hline \multicolumn{8}{|l|}{ Pariambus typicus } \\
\hline \multicolumn{8}{|l|}{ Synchelidium haplocheles } \\
\hline \multicolumn{8}{|l|}{ Westwoodila rectirostris } \\
\hline Westwoodilla sp. & & & & & & & \\
\hline
\end{tabular}

Only taxa accounting for $80 \%$ of total density per sediment type are shown. Only taxa which occurred in at least two samples from a certain sediment type were considered exclusive. $V F-F$ very fine to fine sand, $M$ medium sand, $C-G$ coarse sand to gravel

more abundant in the latter sediment type than in medium sands, whereas Bathyporeia spp. were preferentially collected in medium sands compared with coarser sediments.

Due to the specificity of maerl substrate, samples from this type of bottom were analyzed separately. In maerl beds, 27 amphipod taxa were collected. Samples were characterized by an extremely high dominance level of caprellids of the genus Caprella (62.9\% of total density). Only six taxa accounted for $80 \%$ of total abundance, namely (besides Caprella spp.) Lembos websteri, Leptocheirus pectinatus, Photis spp., Lysianassidae and Cheirocratus sundevalli (Table 3). Gammarella fucicola (Leach, 1814) was exclusive to maerl beds.

Species affinities were also assessed by means of cluster analysis (Fig. 6). The results indicated that groups 1, 2, and 3 were separated from groups based on depth differences. Spe- 


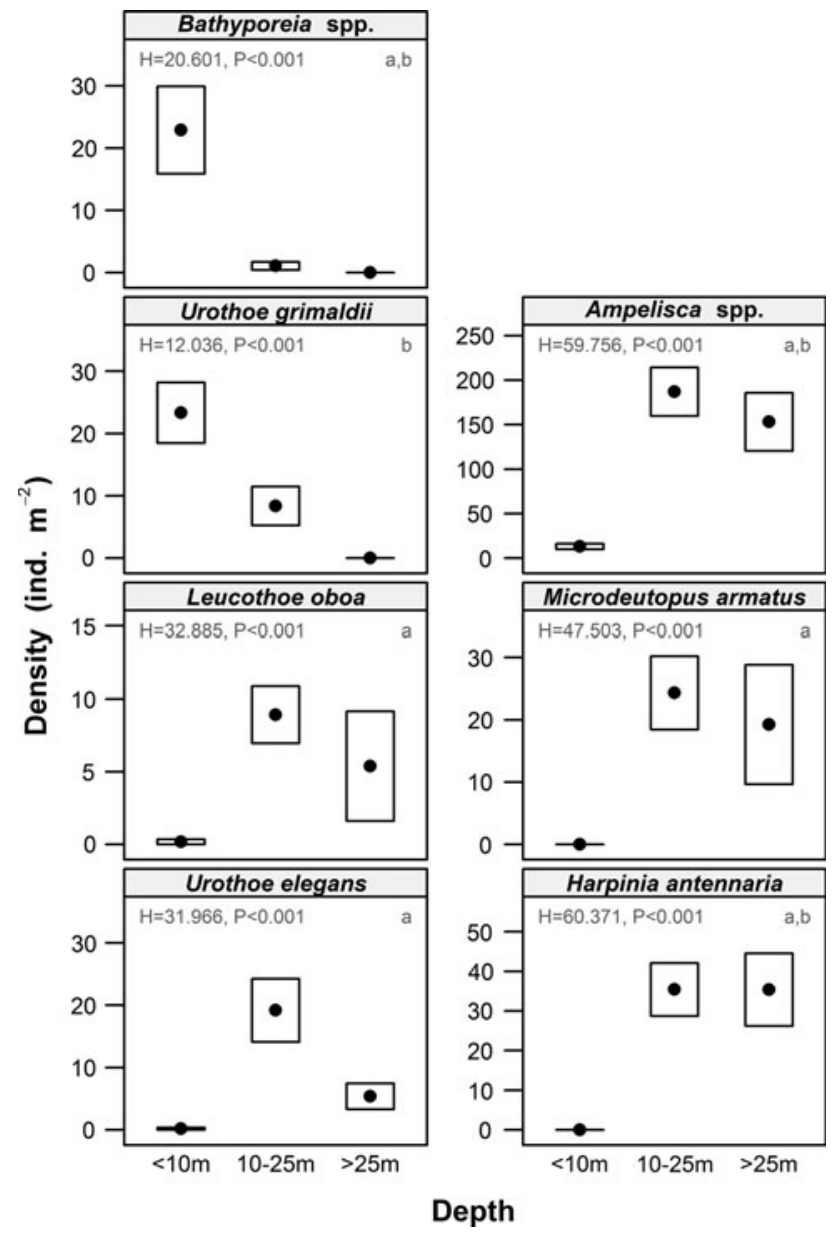

Fig. 4 Boxplots showing mean density and standard error (box) for the amphipod taxa with a significant relationship with depth. $a$, significant differences between $<10$ and $10-25 \mathrm{~m}$ depth; $b$, significant differences between $<10$ and $>25 \mathrm{~m}$ depth; $c$, significant differences between $10-25 \mathrm{~m}$ and $>25 \mathrm{~m}$ depth, $P<0.05$

cies of groups 1, 2, and 3 were mainly associated with samples collected from shallow waters down to $10 \mathrm{~m}$ depth, while species of group 4 were chiefly distributed on deeper bottoms. The separation of groups 1, 2, and 3 were less evident. In general, group 3 comprises species especially abundant in medium sands (except Megaluropus agilis, dominant in coarse sediments), while Leucothoe incisa and Autonoe denticarpus (Myers \& McGrath, 1978) (group 1) were mainly associated with coarse sand to gravel. The separation of species of group 2 was not clear; two species (Siphonoecetes neapolitanus and Urothoe intermedia) were mainly associated with medium sands, while Urothoe poseidonis was more frequent in coarse sediments. Most of the species of group 4 were preferentially distributed between 10 and $25 \mathrm{~m}$ depth in very fine to fine sands [Gammaropsis sophiae (Boeck, 1861), Harpinia pectinata Sars, 1891, Microdeutopus armatus, Ampelisca spp., Urothoe elegans, Orchomenella nana) or on maerl bottom (Gammaropsis sp., Cheirocratus sundevalli, Leptocheirus pectinatus and Caprella spp.].

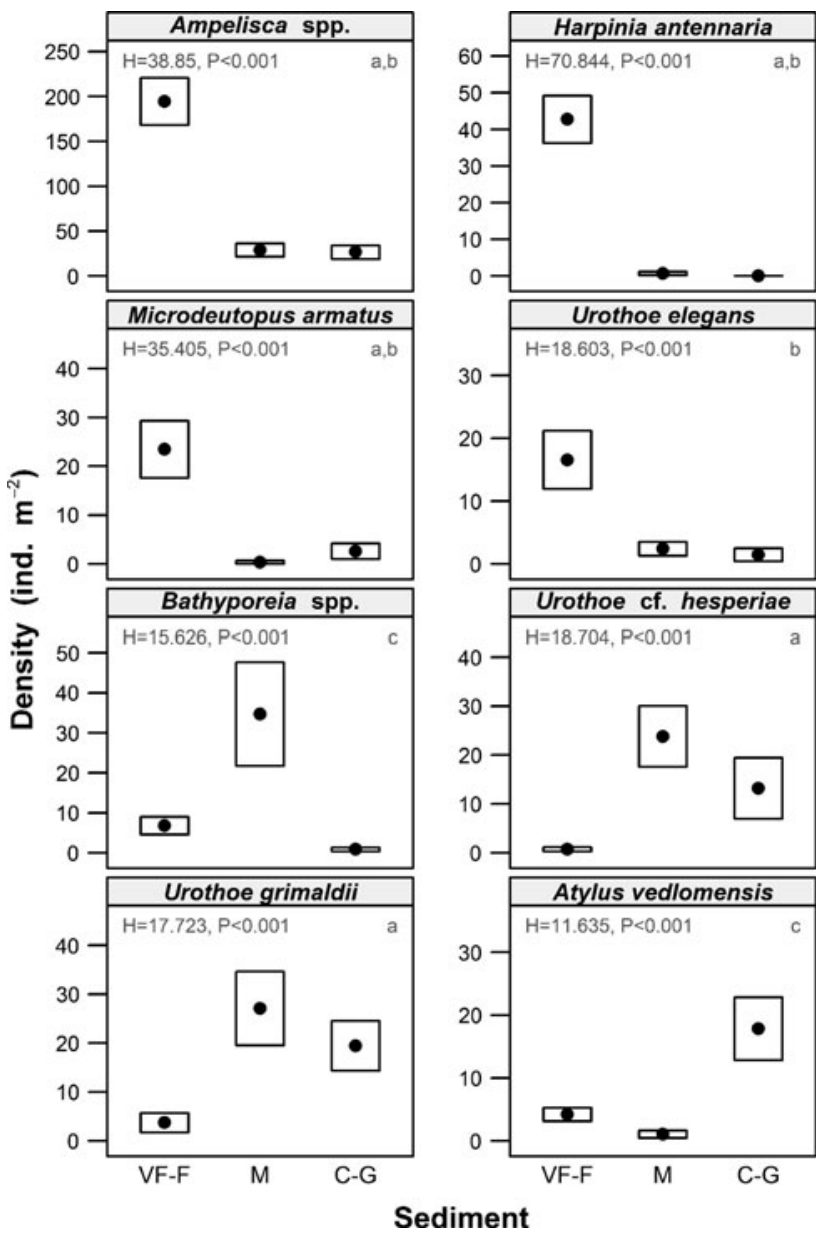

Fig. 5 Boxplots showing mean density and standard error (box) for the amphipod taxa with a significant relationship with sediment type. $a$, significant differences between $\mathrm{VF}-\mathrm{F}$ and $\mathrm{M} ; b$, significant differences between VF-F and $\mathrm{C}-\mathrm{G}$; $c$, significant differences between $\mathrm{M}$ and C-G, $P<0.05$

\section{Biogeography}

Most recorded species have an Atlantic-Mediterranean distribution, corresponding to groups I-II and accounting for $72 \%$ of the total number of taxa (Fig. 7). The number of taxa common to the Atlantic, the Mediterranean, and the Indo-Pacific Ocean (group IV) was high (12\%), while only $5 \%$ of the taxa were exclusive for Atlantic waters (group III).

\section{Discussion}

Distribution of amphipod assemblages in relation to depth

The study of amphipod assemblages along the southern Portuguese coast in relation to habitat features (sediment type and bathymetry) showed that depth may be a major physical factor affecting the spatial distribution and composition of 
Fig. 6 Cluster diagram of species present in more than $5 \%$ of samples based on the BrayCurtis similarity index

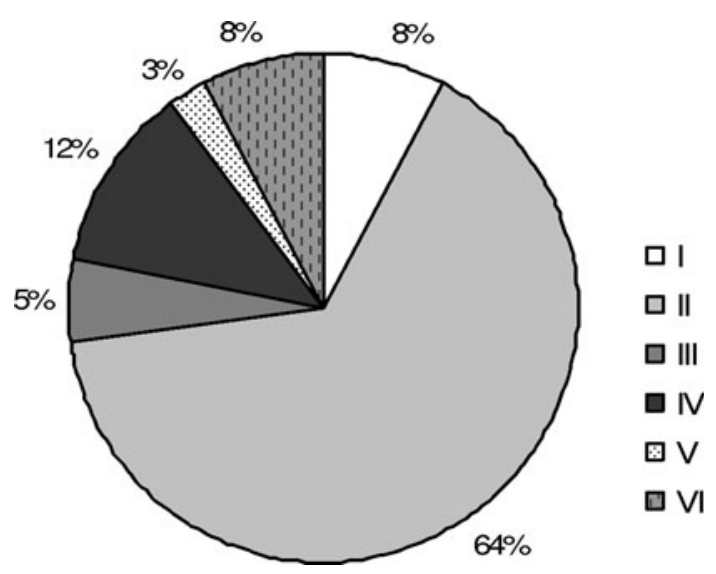

Fig. 7 Percentage of recorded taxa belonging to the following groups of geographical distribution. I-Mediterranean endemic; II-Atlantic, present in the Mediterranean; III-Atlantic, absent from the Mediterranean; IV-Atlantic, present in the Mediterranean and Indo-Pacific Ocean; V-Atlantic, present in the Indo-Pacific Ocean; VI-Cosmopolitan

these crustaceans. Despite the occurrence of different sediment types along the depth profile, biological samples were mainly separated according to depth. The main segregation was observed between samples collected in shallow waters $(<10 \mathrm{~m})$ and those from greater depth levels. These two major groups showed distinct community patterns with more diverse and abundant assemblages in sediments deeper than $10 \mathrm{~m}$.

Along the depth profile, changes are observed in several environmental characteristics such as food availability (namely primary productivity), temperature, and bottom stability, the latter being correlated with the influence of waves, wind, and storm events (Hernández-Arana et al.
2003; Snelgrove 1998). In the present study, environment harshness, in terms of wave impact, came along with decreased diversity and density. When analyzing a depth gradient in the central part of the southern Portuguese coast, Dolbeth et al. (2007) also found lower values of these biological variables in the shallower and more hydrodynamic areas. The influence of the hydrodynamics on the distribution of macrobenthic communities was also reported in other studies (Cunha et al. 1997; Janssen and Mulder 2005; Martínez and Adarraga 2001; Munilla and San Vicente 2005; San Vicente and Sorbe 1999). In the present study, the number of exclusive taxa, diversity and density peaked between 10 and $25 \mathrm{~m}$ depth. This may reflect an abatement of physical constraints caused namely by waves, allowing for the establishing of a higher number of species. Indeed, for the central part of the southern Portuguese coast, Dolbeth et al. (2007) found that active depths, i.e., depths at which hydrodynamics is higher, can be extended up to $10 \mathrm{~m}$ deep. As to the relationship between density and diversity, however, we found increase of density with depth.

Distribution of amphipod assemblages in relation to sediment grain-size

Significant relationships between density/diversity and sediment type were also detected for the amphipod assemblages. Higher diversity and density were observed in finer and medium grain-size sediments, in accordance with amphipod assemblages reported previously for the Portuguese coast (Marques and Bellan-Santini 1990b). Finer sediments usually present higher organic matter content 
(Carvalho et al. 2006a; Sousa et al. 2007), which is an important food resource for benthic communities (Rodríguez-Graña et al. 2008). Moreover, the existence of finer sediments also reflects low levels of physical disturbance. Very fine to fine sands mainly occur beyond the depth of closure, i.e., at depths where beach-nearshore profiles display minor vertical change, and limited net sediment transport is expected to occur (Nicholls et al. 1998). Along the central to the eastern part of the south Portuguese coast, this depth was estimated to 6-10 m (Andrade 1990; Ferreira et al. 2000). The depth of closure reflects differences in hydrodynamics, with lower energy conditions seawards this limit (Dolbeth et al. 2007), which is in accordance with the present findings. Therefore, both increased food availability and reduced disturbance may allow for the existence of richer and denser assemblages. In contrast, coarser sediments are known to generally support lower density and richness values (e.g., Hoey et al. 2004), which was also observed for the amphipod assemblages of southern Portugal.

A particular location characterized by maerl presented a peak of density and was not considered for the regression analysis. In terms of sediment particle size analysis, samples were classified as gravel, produced by looselying coralline red algae (Rhodophyta, Corallinales) or unattached calcified red algae. These forming algae can be regarded as 'ecological engineers' (Steller et al. 2003), creating ecological conditions which allow the establishment of a high number of species with distinct functional traits (De Grave 1999; Sciberras et al. 2009; Steller et al. 2003). Considering the particular features of these habitats, amphipod assemblages of maerl beds may be expected to diverge from those typical of clean sandy areas. To our knowledge, this is the first description of macrobenthic communities of Portuguese maerl beds, and this is particularly relevant as these are priority conservation areas (Barbera et al. 2003; Birkett et al. 1998; Grall and Hall-Spencer 2003; Wilson et al. 2004). Maerl beds serve as nurseries for the juveniles of several commercial species (Kamenos et al. 2004). In Galicia (NW Spain), commercial bivalves (Pecten maximus, Aequipecten opercularis, Mimachlamys varia and Venerupis spp.) are also gathered from maerl habitats (Peña and Bárbara 2009). Besides fishing, dredging, eutrophication, and aquaculture are known to threaten these highly diverse habitats (Barbera et al. 2003; Grall and Hall-Spencer 2003; Hall-Spencer and Moore 2000; Hall-Spencer et al. 2006). A study on the crustacean community associated with maerl habitats in Ireland showed that the 48 amphipod taxa collected accounted for more than $95 \%$ of the community's abundance (De Grave 1999). Nevertheless, this dominance of amphipods was not always observed; other studies reported the co-dominance of molluscs, crustaceans, and annelids (Sciberras et al. 2009). Maerl bottoms are characterized by high species diversity, although most dominant species are not exclusively associated with them (De Grave 1999; Sciberras et al. 2009; and the present study). Rather than the occurrence of exclusive species, it is the overall species assemblage that makes these habitats unique (Sciberras et al. 2009). In some studies, amphipod assemblages of maerl beds were found similar to those of gravel bottoms, which were linked to similar hydrodynamic conditions and the threedimensional sediment structure in terms of large interstitial cavities (De Grave 1999). The dominance of caprellids, lysianassids, Leptocheirus pectinatus (Corophiidae), and Cheirocratus sundevalli (Cheirocratidae) had also been reported by De Grave (1999) and Axelsson et al. (2008). Axelsson et al. (2008) also found Gammarella fucicola as a dominant species within maerl beds. Although not dominant in the present study, Gammarella fucicola was exclusively collected within this area. However, this species is not exclusively associated with maerl, as it was already collected in other distinct habitats, both intertidal (Carvalho et al. 2006b) and subtidal (Carvalho et al. 2007, 2009) areas of the Ria Formosa lagoon (southern Portuguese coast).

\section{Ecological patterns of dominant taxa}

In the present study, the ten most abundant taxa accounted for $67.5 \%$ of the total density (Ampelisca spp., Siphonoecetes dellavallei, Caprella spp., Harpinia antennaria, Urothoe grimaldii, Bathyporeia spp., Urothoe cf. hesperiae, Medicorophium annulatum, Microdeutopus armatus and Siphonoecetes kroyeranus). The dominance of Ampelisca spp. may be biased by the identification to genus level only. However, the dominance of ampeliscids is common in softbottom communities (Marques and Bellan-Santini 1991; Poggiale and Dauvin 2001). Marques and Bellan-Santini (1991) suggested that they have a key role as food for many secondary consumers. Nevertheless, different species of ampeliscids are likely to occur along the depth profile and within areas of different sediment types. From the top ten taxa, only four were present across the depth profile (Ampelisca spp., Siphonoecetes dellavallei, Caprella spp. and Medicorophium annulatum). However, they were not equally distributed. Ampelisca spp. and Caprella spp. were dominant in intermediate depths, while Siphonoecetes dellavallei were mainly collected in low depths $(<10 \mathrm{~m})$. Medicorophium annulatum was abundant until the $25 \mathrm{~m}$ isobath. These taxa were also collected from very fine to fine sands to gravel and, except for Medicorophium annulatum, were also present in maerl samples. Although this corophiid has been described as typical of mud (Myers 1982), Conradi and López-González (1999) also collected it in a 
wide variety of substrata. Therefore, and assuming that depth is an important factor for the spatial distribution of amphipods, the species previously reported may be less specific with respect to environmental conditions, particularly down to $40 \mathrm{~m}$ depth.

Bathyporeia spp., Urothoe grimaldii, Urothoe cf. hesperiae, and Microdeutopus armatus were also recorded from very fine sand to gravel, but their spatial distribution was limited by depth. Microdeutopus armatus was absent from samples collected down to $10 \mathrm{~m}$. The remaining species were only present down to $25 \mathrm{~m}$ depth and were especially abundant until $10 \mathrm{~m}$ depth or, in the case of Urothoe cf. hesperiae, evenly distributed until $25 \mathrm{~m}$. Urothoe cf. hesperiae was also recorded in the Algeciras Bay from 3 to $30 \mathrm{~m}$, while species of the genus Bathyporeia and Urothoe grimaldii are very typical of shallow water sandy areas (Conradi and López-González 1999; Hoey et al. 2004; Lourido et al. 2008; Marques and Bellan-Santini 1991, 1993; Scipione et al. 2005). Although it did not range among the ten most abundant species, another urothoid was collected in this study (Urothoe elegans). While the previous urothoiids were mainly observed in medium sands, Urothoe elegans was preferentially distributed in fine sands between 10 and $25 \mathrm{~m}$ depth. Therefore, three species of the same genus show different ecological traits, which is worth noting when inferring such traits at higher taxonomic levels. Harpinia antennaria presented a density peak between 10 and $25 \mathrm{~m}$ depth and was absent from the shallowest areas. Siphonoecetes kroyeranus proved to be more habitat-specific, as it was only recorded down to $10 \mathrm{~m}$ depth and was absent from the coarsest sediments. This species has been reported as dominant in both Atlantic (Moreira et al. 2008) and Mediterranean (San Vicente and Sorbe 1999) beach sediments, and in fine to medium sandy bottoms of Galician rias (Lourido et al. 2008) which is in accordance with the present findings.

\section{Biogeographic notes}

Amphipods are often expected to have an endemic tendency due to their limited dispersal capacity, resulting both from the direct development and from reduced swimming capacity (Marques and Bellan-Santini 1990a). Conradi and LópezGonzález (1999) found a typical Mediterranean amphipod community (although with only $18 \%$ endemic species, compared to $38 \%$ in the Mediterranean) in Algeciras Bay (Strait of Gibraltar), the westernmost part of the Mediterranean Sea. In the present study, Atlantic-Mediterranean amphipods were well represented on the southern Portuguese coast, and the occurrence of $8 \%$ of Mediterranean endemic species may reflect the extension of the Mediterranean fauna beyond the Strait of Gibraltar. Previous studies on benthic amphipods (Marques and Bellan-Santini 1990a) and on brachyurans
(Almaça 1985) along the Portuguese coast showed a high affinity with the Mediterranean fauna, highlighting the relevance of this area as a biogeographic transition between Atlantic and Mediterranean. Therefore, the classification of the southern Portuguese benthic fauna as Atlantic-Mediterranean was once more confirmed in the present study. Nevertheless, as amphipods are sensitive to changes in seawater temperature (e.g., Lawrence and Soame 2004), the distribution patterns of amphipod assemblages are also expected to change in a global warming scenario. In this context, the present study may provide valuable baseline information to ascertain potential future impacts of climate change.

Acknowledgments The major part of the data was provided by different research projects, namely: DREDGIMPACT (POCTI/MGS/ 42319/2001); Implantação e Estudo Integrado de Sistemas Recifais (carried out within the MARE program); Estação Piloto de Aquicultura Off-Shore (22-04-06-IFP-002 carried out within the MARE program). Part of this work also had the institutional support of INAG-National Water Institute (Portugal). The authors are grateful to all the colleagues who assisted in sampling campaigns and processing macrobenthic samples (to name a few, A. Moura, J. Tata Regala, F. Leitão, P. Pereira, R. Constantino, L. Cancela da Fonseca) and T. Drago for sediment characterization. Thanks are also due to the crew of RV DONAX and the technicians T. Simões, J. L. Sofia and M. L. Inácio for help during sampling. Susana Carvalho benefits from a post-doctoral grant (SFRH/ BPD/26986/2006) awarded by "Fundação para a Ciência e a Tecnologia" (FCT).

\section{References}

Almaça C (1985) Zoogeographical considerations on the Iberian brachyuran fauna (Decapoda, Crustacea). Arq Mus Bocage A $3: 18$

Andrade C (1990) O ambiente de barreira da ria Formosa, Algarve, Portugal. PhD thesis, Universidade de Lisboa, $645 \mathrm{pp}$

Axelsson M, Bamber R, Dewey S, Duke S, Hollies R (2008) Falmouth Cruise Project EIA-Marine Ecological Survey. SeaStar Survey Ltd, Ocean Quay Marina, Belvidere Road, Southampton, SO14 5YQ, UK, p 23

Barbera C, Bordehore C, Borg JA, Glémarec M, Grall J, Hall-Spencer JM, De la Huz C, Lanfranco E, Lastra M, Moore PG, Mora J, Pita ME, Ramos-Esplá AA, Rizzo M, Sánchez-Mata A, Seva A, Schembri PJ, Valle C (2003) Conservation and management of northeast Atlantic and Mediterranean maerl beds. Aquat Conserv Mar Freshw Ecosyst 13:S65-S76

Birkett DA, Maggs CA, Dring, MJ (1998) Maerl (Vol. V) An overview of dynamic and sensitivity characteristics for conservation management of marine SACs. Scottish Association for Marine Science. (UK Marine SACs Project), $116 \mathrm{pp}$

Carvalho S, Gaspar MB, Moura A, Vale C, Antunes P, Gil O, Cancela da Fonseca L, Falcão M (2006a) The use of the marine biotic index AMBI in the assessment of the ecological status of the Óbidos lagoon (Portugal). Mar Pollut Bull 52:1414-1424

Carvalho S, Moura A, Sprung M (2006b) Ecological implications of removing seagrass beds (Zostera noltii) for bivalve aquaculture in southern Portugal. Cah Biol Mar 47:321-329

Carvalho S, Barata M, Gaspar MB, Pousão-Ferreira P, Cancela da Fonseca L (2007) Enrichment of aquaculture earthen ponds with Hediste diversicolor: consequences for benthic dynamics and natural productivity. Aquaculture 262:227-236 
Carvalho S, Falcão M, Cúrdia J, Moura A, Serpa D, Gaspar MB, Dinis MT, Pousão-Ferreira P, Cancela da Fonseca L (2009) Benthic dynamics within a land-based semi-intensive aquaculture fish farm: the importance of settlement ponds. Aquacult Int 17:571587

Carvalho S, Constantino R, Cerqueira M, Pereira F, Subida MD, Drake $\mathrm{P}$, Gaspar MB (in press) Short-term impact of bait digging on intertidal macrobenthic assemblages of two south Iberian Atlantic systems. Est Coast Shelf Sci doi:10.1016/j.ecss.2011.06.017

Clarke KR, Gorley RN (2001) PRIMER (Plymouth Routines In Multivariate Ecological Research) v5: User Manual/Tutorial. PRIMER-E Ltd, Plymouth

Conradi M, López-González PJ (1999) The benthic Gammaridea (Crustacea: Amphipoda) fauna of Algeciras Bay (Strait of Gibraltar): distributional ecology and some biogeographical considerations. Helgol Mar Res 53:2-8

Conradi M, López-González PJ, García-Gómez C (1997) The amphipod community as a bioindicador in Algeciras Bay (Southern Iberian Peninsula) based on a spatial-temporal distribution. PSZN: Mar Ecol 18:97-111

Cunha MR, Sorbe JC, Bernardes C (1997) On the structure of the neritic suprabenthic communities from the Portuguese margin. Mar Ecol Prog Ser 157:119-137

De Grave S (1999) The influence of sedimentary heterogeneity on within maerl bed differences in infaunal Crustacean community. Est Coast Shelf Sci 49:153-163

Dolbeth M, Ferreira Ó, Teixeira H, Marques JC, Dias JA, Pardal M (2007) Beach morphodynamic impact on a macrobenthic community along a subtidal depth gradient. Mar Ecol Prog Ser 352:113124

Ferreira Ó, Ciavola P, Taborda R, Bairros M, Dias JA (2000) Sediment mixing depth determination for steep and gentle foreshores. J Coast Res 16:830-839

Gamito S (1989) The benthic macrofauna of some water reservoirs of salt-pans from Ria Formosa (Portugal). In: Ros JD (ed). Topics in Marine Biology. Sci Mar 53:639-644

Grall J, Hall-Spencer JM (2003) Problems facing maerl conservation in Brittany. Aquat Conserv: Mar Freshw Ecosyst 13:55-64

Guerra-García JM, García-Gómez JC (2002) The spatial distribution of Caprellidea (Crustacea: Amphipoda): a stress bioindicator in Ceuta (North Africa, Gibraltar Area). Mar Ecol 22:357-367

Hall-Spencer JM, Moore PG (2000) Scallop dredging has profound, long-term impacts on maerl habitats. ICES J Mar Sci 57:1407-1415

Hall-Spencer J, White N, Gillespie E, Gillham K, Foggo A (2006) Impact of fish farms on maerl beds in strongly tidal areas. Mar Ecol Prog Ser 326:1-9

Hernández-Arana HA, Rowden AA, Attrill MJ, Warwick RM, GoldBouchot G (2003) Large-scale environmental influences on the benthic macroinfauna of the southern Gulf of Mexico. Est Coast Shelf Sci 58:825-841

Hoey GV, Degraer S, Vincx M (2004) Macrobenthic community structure of soft-bottom sediments at the Belgian continental shelf. Est Coast Shelf Sci 59:599-613

Hurlbert SH (1971) The non-concept of species diversity: a critique and alternative parameters. Ecology 52:577-586

Janssen G, Mulder S (2005) Zonation of macrofauna across sandy beaches and surf zones along the Dutch coast. Oceanologia 47:265-282

Kamenos NA, Moore PG, Hall-Spencer JM (2004) Small-scale distribution of juvenile gadoids in shallow inshore waters; what role does maerl play? ICES J Mar Sci 61:422-429

Lawrence AJ, Soame JM (2004) The effects of climate change on the reproduction of coastal invertebrates. Ibis 146:29-39

Lock K, Mees J (1999) The winter hyperbenthos of the Ria Formosa: a lagoon in southern Portugal-and adjacent waters. Cah Biol Mar 40:47-56
Lourido A, Moreira J, Troncoso JS (2008) Assemblages of peracarid crustaceans in subtidal sediments from the Ría de Aldán (Galicia, NW Spain). Helgol Mar Res 62:289-301

Mackie ASY, Parmiter C, Tong LKY (1997) Distribution and diversity of Polychaeta in the Southern Irish Sea. Bull Mar Sci 60:467-481

Magurran AE (1988) Ecological diversity and its measurement. Princeton University Press, Princeton

Marques JC, Bellan-Santini D (1985) Contribution à l'étude systématique et écologique des amphipodes (Crustacea-Amphipoda) des côtes du Portugal. Premier inventaire des espèces (Gammariens et Caprelliens). Cienc Biol Ecol Syst 5:131-149

Marques JC, Bellan-Santini D (1986) Crustacés Amphipodes des côtes du Portugal: faune du canal de Tavira, des salines de Marim (Ria Formosa) et de la lagune de Santo André. An Fac Cienc Porto 67:217-243

Marques JC, Bellan-Santini D (1987) Crustacés Amphipodes des côtes du Portugal: Faune de l'estuaire du Mira (Alentejo, côte sud-ouest). Cah Biol Mar 28:465-480

Marques JC, Bellan-Santini D (1990a) Benthic amphipod fauna (Crustacea) of the Portuguese coast: biogeographical considerations. Mar Nat 3:43-51

Marques JC, Bellan-Santini D (1990b) Faune d'amphipodes des milieux lagunaires du Portugal: actualisation des données et comparaison avec d'autres systèmes atlantiques et méditerranées. Mésogée 50:53-61

Marques JC, Bellan-Santini D (1991) Gammaridea and Caprellidea (Crustacea-Amphipoda) of the Portuguese south-western continental shelf: taxonomy and distributional ecology. Bijdr Dierkd 61:65-87

Marques JC, Bellan-Santini D (1993) Biodiversity in the ecosystem of the Portuguese coastal shelf: distributional ecology and the role of benthic amphipods. Mar Biol 115:555-564

Martínez J, Adarraga I (2001) Distribución batimétrica de comunidades macrobentónicas de sustrato blando en la plataforma continental de Guipúzcoa (golfo de Vizcaya). Bol Inst Esp Oceanogr $17: 33-48$

Myers AA (1982) The family Corophiidae. Mem Inst Oceanogr (Monaco) 13:185-208

Monteiro Marques V (1979) Contribuition à l'étude du plateau continental des côtes portugaises (Algarve, sud Portugal): étude des peuplements de substrats meubles. Tethys 9:191-195

Moreira J, Gestoso L, Troncoso JS (2008) Diversity and temporal variation of peracarid fauna (Crustacea: Peracarida) in the shallow subtidal of a sandy beach: Playa América (Galicia, NW Spain). Mar Ecol 29:12-18

Munilla T, San Vicente C (2005) Suprabenthic biodiversity of Catalan beaches (NW Mediterranean). Acta Oecol 27:81-91

Nicholls RJ, Birkemeier WA, Lee G (1998) Evaluation of depth of closure using data from Duck, NC, USA. Mar Geol 148:179-201

Peña V, Bárbara I (2009) Distribution of Galician maerl beds and their shape classes (Atlantic Iberian Peninsula): proposal of areas in future conservation plans. Cah Biol Mar 50:353-368

Poggiale J-C, Dauvin J-C (2001) Long-term dynamics of three benthic Ampelisca (Crustacea-Amphipoda) populations from the Bay of Morlaix (western English Channel) related to their disappearance after the 'Amoco Cadiz' oil spill. Mar Ecol Prog Ser 214:201-209

Rodrigues AM, Dauvin J-C (1987) Crustacés péracarides de la Ria de Alvor (côte sud du Portugal). Cah Biol Mar 28:207-223

Rodríguez-Graña L, Calliari D, Conde D, Sellanes J, Urrutia R (2008) Food web of a SW Atlantic shallow coastal lagoon: spatial environmental variability does not impose substantial changes in the trophic structure. Mar Ecol Prog Ser 362:69-83

San Vicente C, Sorbe JC (1999) Spatio-temporal structure of the suprabenthic community from the Creixell beach (western Mediterranean). Acta Oecol 20:377-389

Sanders ML (1968) Marine benthic diversity: a comparative study. Am Nat 102:243-282 
Sciberras M, Rizzo M, Mifsud JR, Camilleri K, Borg JA, Lanfranco E, Schembri PJ (2009) Habitat structure and biological characteristics of a maerl bed off the northeaster coast of the Maltese Islands (central Mediterranean). Mar Biodiv 39:251-264

Scipione MB, Lattanzi L, Tomassetti P, Chimenz Gusso C, Maggiore F, Mariniello L, Cironi R, Taramelli E (2005) Biodiversity and zonation patterns of crustacean peracarids and decapod of coastal soft-bottom assemblages (central Tyrrhenian Sea, Italy). Vie Millieu 55:143-161

Snelgrove PVR (1998) The biodiversity of macrofaunal organisms in marine sediments. Biodivers Conserv 7:1123-1132

Sousa Reis C, Monteiro Marques V, Calvário J, Marques JC, Melo R, Santos R (1982) Contribuição para o estudo dos povoamentos bentónicos (substrato móvel) da costa occidental portuguesa. Actas do $2^{\circ}$ Simpósio Ibérico de Estudos de Bentos Marinho. Oecol Aquat 6:91-105

Sousa R, Dias S, Freitas V, Antunes C (2007) Subtidal macrozoobenthic ssemblages along the River Minho estuarine gradient (northwest Iberian Península). Aquat Conserv Mar Freshw Ecosyst 18:1063-1077
Sprung M (1994) Macrobenthic secondary production in the intertidal zone of the Ria Formosa-a Lagoon in Southern Portugal. Est Coast Shelf Sci 38:539-558

Steller DL, Riosmena-Rodríguez R, Foster MS, Roberts CA (2003) Rhodolith bed diversity in the Gulf of California: the importance of rhodolith structure and consequences of disturbance. Aquat Conserv Mar Freshw Ecosyst 13:S5-S20

Wilson S, Blake Ch, Berges JA, Maggs CA (2004) Environmental tolerances of free-living coralline algae (maerl): implications for European marine conservation. Biol Conserv 120:279-289

Ysebaert T, Meire P, Herman PMJ, Verbeek H (2002) Macrobenthic species response surfaces along estuarine gradients: prediction by logistic regression. Mar Ecol Prog Ser 225:79-95

Zar JH (1996) Biostatistical analysis, 3rd edn. Prentice-Hall International Inc., Englewood Cliffs

Zenetos A, Revkov NK, Konsulova T, Sergeeva N, Simboura N, Todorova VR, Zaika VE (2000) Coastal benthic diversity in the Black and Aegean Seas. Mediterr Mar Sci 1(2):105-117 